\title{
A STUDY OF MANJU KAPUR'S CUSTODY FROM A FEMINIST PERSPECTIVE
}

\author{
S. Manimekalai ${ }^{1 *}$, Dr. V. Vimala ${ }^{2}$ \\ ${ }^{1}$ Assistant Professor, PSNA College of Engineering \&Technology, Dindigul. \\ ${ }^{2}$ Assistant Professor Cardamom Planter's College, Theni
}

\begin{abstract}
Ina traditional Indian society, women find space as a living being. She needs to be a wife and mother first and then a living being with heart and head. Right from childhood, women have been trained to suppress their physical needs, keeping their families' interest foremost in their minds. Sex is something forbidden to them, and it is treated as a cause for challenges and catastrophes. Under the pretext of maintaining tradition, female sexuality has been suppressed. Instead, it has been appreciated in exalted terms by glorifying motherhood. Infertility in married life affects both husband and wife, yet it is the woman who usually carries the social stigma. Women's social status, how they are regulated in life, economic independence, survival, and marital life are all equivalent to nothing unless their married life becomes fruitful. In this connection, Anderson opines," motherhood is generallyrecognized as an essential part of being a woman, to an extentpoint that women without children are usually described as unsatisfied and incomplete" (42). For a woman whose married life is barren,her body itself becomes an object of discontentment. This paper attempts to view the female body in Manju Kapur's Custody novel from a feminist perspective.
\end{abstract}

Keywords

Infertility, Barren, Motherhood, Wifehood, Biological Mother, Adoption.

Article Received: 20 September 2020, Revised: 30 November 2020, Accepted: 18 December 2020

\section{Introduction}

Attaining motherhood is considered as a task well accomplished by all married women. The failure to attain motherhood is viewed with utmost contempt. She becomes vulnerable to all sorts of rebukes and psychological pressures from the family and the society. Infertility in married life becomes the root cause for filing divorce. Therefore, it is imperative to understand the barrenness in married life both in terms of physical sense and also in social concern. In the culture of Indian, the parts played by motherhoods are inculcated into thegirl child's mind since from the childhood then they are encouraged to enact the roles of mothers for their younger siblings or with dolls. Their capacity to reproduce is made conscious from childhood and once they reach the puberty stage,their capability to reproduce is appreciated by conducting a family function. The stage before a woman attaining motherhood is the marriage stage. It is enacted with all pomp and splendor. It happens to be the biggest ceremony in a woman's life. In Indian tradition, marriage is viewed as a social and religious custom and in it love has only a peripheral role to play. Marriage is a passport for attaining motherhood. The rituals performed during the marriage and after it are meant for attaining motherhood. In Custody novel, Manju Kapur discusses motherhood from a different perspective and suggests alternative means for attaining motherhood such as step mothering. It is a very positive step taken for protecting women suffering from biological childlessness as it permits to explore other possible means of attaining motherhood. Simon de Beauvoir came without his observation that women have been trained from their infancy to get ready for childbearing. There are many who glorify the pleasures of bearing a child whereas there are not many to explain about the hardships of menstruation, illnesses and the day today household drudgery. Beauvoir further observes that women have been under the impact of sustained pervasiveness from the society since their childhood and are made to embrace motherhood willingly. In order to isolate women from their own body skills, it is necessary to institutionalize their bodies.

"motherhood is seen as an institution of patriarchy that ensures the control of women by their imprisonment in domesticity. It is seen to regulate women to the private world of child-bearing and rearing apart from the public world of wage earning and decision making and the intellectual and academic world of creative thinking and writing." (Saharan, Asha : 69)

\section{CUSTODY FROM A FEMINIST PERSPECTIVE}

Woman attaining motherhood is considered as a major achievement of her life and there are derogatory terms earmarked for referring to who do not attain it. Terms such as 'barren' and 'childless' is referred to only women and no male is called 'non father'. In the society, women bodies are considered as high-tech reproductive technology. In this context, it is pertinent to mention the observations of Adrienne Rich who states that in the patriarchal setup, a woman attaining motherhood is no more a human condition and instead it is rape. There are patriarchal forces in the society who glorify mothers, motherhood and recognize their normative quality. As per Adirenne Rich,

"parenthood of women isn't just a center human relationship , however a political organization ,

a cornerstone to the control in each circle of ladies by men." (216)

In Custody novel, the protagonist Ishita hails from a middle class family and her life is affected by moral values and 
social taboo practiced in a patriarchal setup. She is from an orthodox family practicing Indo-Aryan codes on morality. For them:

" marriage keeps on having material, social and representative implications

also, outcomes which are awry regarding their suggestions for females

also, guys in at any rate three huge ways. Right off the bat, selfhood, decency and status

are attached to wifehood and parenthood in more demanding manners than they are to being a

spouse and/or father. A solitary man or man without kids is viewed as shocking,

however, a lady in a comparable circumstance is ominous , perhaps risky. ( Palriwala: 400-401).

Ishita enters into a wedlock with a gentleman arranged by her parents. Very soon her married life runs into rough weather due to her inability to attain pregnancy. In spite of various treatments given to her, she is not able to become fruitful. She gets disturbed psychologically. She mutters :"littler than the ants on the ground, littler than the bits of the residue in the sunlit air, littler than drops of dew got between pieces of sod toward the beginning of the day was Ishita as she sat in the gynecologist's office."( 65) Since Ishita has problems in getting conceived, she is shabbily treated by her family members and the society. In their eyes, she is incomplete' and 'worthless'. Reber rightly points out: "childbearing has been seen as a significant sexual orientation explicit function to ladies. Accordingly ladies who can't manage kids, experience an inescapable Feeling of individual disappointment." ( 674).

From the novel, it is evident that utmost importance is given to material possession and terms and conditions entered before enacting a marriage looks lopsided. The mother in law of Ishita opines:

" for us cash isn't significant as family.But, beta, it is fundamental that Suryakanta have a kid. As the main child, he needs to ensure that the Bloodline of his ancestors proceeds." ( 69).

She also opines that:

" she was unable to imagine, whereupon SK had concluded he could not love her." ( 127).

From the beginning itself, it became quite apparent that the married life of Ishita would fail.it became a failure due to her inability in attaining pregnancy. It is purely a biological reason and she has no role to play in it.

The author Manju Kapur gives telling account of the oppressive and gender discriminating norms followed by certain sections in the society. The author exhibits a version of the family which is more concerned with the material possession and Ishita's in law is a very good example for it. She says" for us, the young lady's characteristics were everything. You realize we requested no settlement.?" ( 69). Consequently, their reaction is that when a woman is unable to attain pregnancy, then she does not have right qualities to have descendants. Then, a mutual consent has to be worked out for divorce and some kind of cash settlement has to be worked out. Ishita suffers from mental trauma since, "the mother bean to all her shameless, the sisters refused to talk to her, the father and SK avoided her."( 72). Ishita proves to be very vulnerable is ashamed of everything. In the early stages of married life, she suffers due to identity lacks and nurtures an opinion that the women cannot carrying out her partproperly. The mother in law of women is least inclined to spend any cash on womenwhich makes the womensorely contemplate:

" had there been something wwrong with S.K., they would have moved

paradise and earth to get a child's deformity adjusted. In an ideal world the equivalent

assets would have been put at the removal of a girl - in law.

In any case, this was not an ideal world." ( 68).Ishita very rapidly loses her health as well as self esteem due to her barrenness in married life""hadn't they esteemed her for herself? Being a childless, consigns her to the status of a ' no one' as she has neglected to demonstrate her womanliness through youngster bearing. This is my karma, nothing will break it." ( 68).Due to her barrenness, her married life with Surkakanta is as good as a ship laboring in a storm. It is her physique which has made the womenweak to the culture:

"The women's bodyimagined that had known so much love and afterward to such an extent Discipline. Later she despised her body, loathed it. Oppression of science is what's amiss with the general public" ( 138).

The woman nurtures a kind of disaffection from her physique and examines it in a meticulous manner. She is troubled by feelings such as self hatred and insufficiency and it leads to weakening her confidence. she relegates in doldrums. In a patriarchal society, a woman's physique is considered as nothing but a a product and property. She is troubled by a vexing question. How long can she disengage her physique from others. Ishita is both a product as well as theprisoner ofher own generativeframework where the own body of women is the battleground for her own freedom fights.

Ishita experiences 'affected exile'that the physique of ishita senses severed from the pain as if it is unfamiliar to ishita. In the domestic life, she is considered as a failure. Since her failure is a biological one, she starts underestimating herself. She suffers due to twin diasters. The first is as astranger to masculine powers and then a woman that she is unable to attain fertility. In an orthodox set up, a woman becomes powerless in the event of not being able to attain fertility in married life. As ill luck would have it, Ishita is given marching orders from the house and she feels her fate to be due to her inadequate body. Her married life ends with a divorce and she becomes much dejected afterwards. She is given a fresh lease in her life as a worker in NGO run by Mrs. Hingorani. Ishita even thinks about adopting a child ,but her psychological weakness and her frequent exposure to an atmosphere where woman are considered as procreators and protectors of the family make her loathe herself: "if only she could tear out her whole reproductive system and throw it on the road."( 127). She loathes her 
body, loathes herself and her mind is thick with negative thoughts.

The novel Custody is an aggressive discourse on the interior world of politics and it finds fault with her as a failure. This feminine project moves to a climatic stage as and when she becomes a primary oppressor like Shagun who is not afraid of crossing the social taboo so as to follow her own ideas sincerely. Ishita enters into a second marriage with Raman and comes back to the position so crudelyrushed from her. Both wife hood and motherhood were taken away from her. Her husband's social position gets uplifted as soon as he marries her. This elevation is quite akin to great women in Indian epics who could make easy access to power and other social honors once they get into contact with men. The love life of the couple is expressed by the author in material aspect;

" at adornments counters lamentably love should be converted into rupees...

They chose a mid-extend one for 30,000/ - .. On Ishita's hand

genuine romance shimmered" ( 302).

After undergoing all kinds of troubles in her life, Ishita is able to come back to her old self with the help of her biological family. She takes a trip down her memory lane and embarks on a fresh journey with hope lending her support. In a phased manner, Ishita is able to get rid of her negative thoughts and show love and affection towards Roohi, a parentless girl. When she comes across Raman, a divorce, two of them are able to develop a healthy rapport. Until then, she never thought anything about her body. She was in a self exilestate. Now, she is able to exert control over her body. As a living being, Ishita had denied any sexual pleasure to her body. But in the company of Raman, she leads a contented relationship in this aspect. In addition, her maternal instincts also get satisfied due to her love towards Roohi.

Both the husband and wife come to an understanding mentally, physically and emotionally. They are wedded in a court and enter into a next phase in their life. Ishita enjoys all kinds of comforts her nuptial with Raman offers to her. Her maternal instincts are in full to the brim and she showers them all over Roohi. She gives utmost importance to Roohi's future. She exudes confidence while facing the the court: "since the time marriage, I have placed her government assistance above everything. I think about her as my fragile living creature and blood. On the off chance that anyone resembles a stage mother, it is this woman. To be a mother you need a heart." ( 412). The Judge questions the girl and Roohi replies in favour of Ishita. Although Ishita is not the biological mother of Roohi, the Judge is convinced of her sincerity in looking after the girl and entrusts her once for all into her custody .In the novel, sheconvertssterility that decodes its actualsense and de-stigmatizes it by the presence the Roohi'sstepmother. ( Saharan: Muse India).

Ishita wins both in wifehood and motherhood. Now, she is able to externalize her infertility problem and because of it, there is no room for any negative thoughts in her mind. The vacuum in her life gets fulfilled through Roohi .
Since Ishita and Raman are able to get synchronized physically and emotionally, they enter into a wedlock in a court discarding the hardships experienced in previous marital relationships. Ishita shows herself as an individual in choosing a life partner. This enables her enjoy both nuptial and motherly bliss. She showers all her motherly love on Roohi and keeps her interest foremost in her mind.

Though not being the biological mother of Roohi, she enjoys all kinds of joy a motherhood could bring to a lady. The body of Ishita was earlier "disempowered by her infertility and now, it developsallowing for her and alsopractices a successfulliberty."( Saharan: 71).

\section{SUMMATION}

Ishita exhibits her individuality in choosing her life partner as well as in adopting Roohi as her child. These two courageous decisions bring joy and happiness in her life. Kapur delves into the intricacies of women's sexual experiences so as to decode several tropes transgression which impact on body and psyche. The author tactfully employs woman's physique as an instrument to question certain controversial social determinants depriving a woman's control over her physique. Her expertise in writing appears to give an idea that the Indian society is in a state of flux and it is imperative to recognize the values of democracy such as dignity, peace and justice a comfortable place. It is time to consider treating women in a dignified manner and let her take important decisions in her life.

\section{WORKS CITED}

[1] Kapur, etCustody .Noida: Random House India, 2011.Print.

[2] Anderson, C.M. Flying Solo: Single Woman in Midlife. New York: W.W. Norton and Company, 1994.Print.

[3] Germine, Greer. The Whole Women. London" Transworld, 1999. Print.

[4] Greene, Gayle. Changing the Story: Feminist Fiction and the Tradition. Indiana UP:

a. Bloomington and Indianapolis, 1991.Print.

[5] De Beauvoir, Simone. The Second Sex. Trans\& ed., H.M. Parshley.Harmondsworth: Penguin, a. 1983.Print.

[6] Kumar, Ashok. "Portrayal of a New Women: A Study of Manju Kapur'sA Married Woman".

[7] R. Sathish, R. Manikandan, S. Silvia Priscila, B. V. Sara and R. Mahaveerakannan, "A Report on the Impact of Information Technology and Social Media on Covid-19," 2020 3rd International Conference on Intelligent Sustainable Systems (ICISS), Thoothukudi, India, 2020, pp. 224-230, doi: 10.1109/ICISS49785.2020.9316046.

[8] Indian Writing in English: Critical Ruminations: Vol.2. Ed. Amarnath and S. John Peter 
[9] Joseph. New Delhi: Sarup and Sons, 2006.p. 194.

[10] Manikandan, $\mathrm{R}$ and Dr.R.Latha (2017). "A literature survey of existing map matching algorithm for navigation technology. International journal of engineering sciences \& research technology", 6(9), 326-331.Retrieved September 15, 2017.

[11] Manohar, Dr.Murali. "Introduction,"Indian English Women's Fiction: A Study of

MarriageCareer and Divorce. New Delhi: Atlantic Publication, 2007. P. 11.

[12] Pandey, Miti. "Primacy of Motherhood", Feminism in Contemporary British and Indian English Fiction. New Delhi: Sarup\& Sons. 2003, p. 98.

[13] Reber, A.S. ( ed). The Penguin Dictionary of Psychology, ( $2^{\text {nd }}$ ed), London: Penguin Books, 1995. Print.

[14] Rich, Adrienne. Of Woman Born: Motherhood as Experience and Institution. New York: Rutgers University Press, 1995.Print.

[15] Sinha, Sunita. Post Colonial Women Writers. New Delhi: Atlantic , 2008.Print.

[16] Swami, Indu. "Search for Identity". The Woman Question in the Selected Novels of

Nayanthara Sahgal, Manju Kapur and Arundhati Roy. New Delhi: Sarup Book Publishers Pvt.Ltd., 2009.p.4.

[17] Saharan, Asha "Treatment of Infidelity and Infertility in Manju Kapur's Custody."Volume

i. II Issue I, www.tjells.com 